DOI: https://doi.org/10.34069/AI/2021.43.07.19

How to Cite:

Dyakiv, K., Korolyov, I., \& Yaremko, M. (2021). Communicative deviations of respondents in political video interviews in Ukrainian and German. Amazonia Investiga, 10(43), 189-199. https://doi.org/10.34069/AI/2021.43.07.19

\title{
Communicative deviations of respondents in political video interviews in Ukrainian and German ${ }^{69}$
}

\section{Комунікативні девіації респондентів у політичних відеоінтерв’ю в українській та німецькій мовах}

Received: June 2, 2021

\begin{abstract}
The research has the objective to establish the peculiarities of communicative deviations as a cognitive and at the same time discursive phenomenon in Ukrainian- and Germanlanguage video interviews from the viewpoint of respondents. The procedure of the research involves the integrated application of methods and techniques of pragmatics, deviatology and communicative linguistics. A new methodological basis has been developed for the reconstruction of communicative deviations using discourse analysis, namely for the reconstruction of a single event in two discursive environments, determining the communicative context and communication of interview in compared languages. The results of the research allow us to identify the features of communicative deviations in political interviews at the external, internal structural levels and at the situational level. The conclusions of the research indicate that the types of communicative deviations in political video interviews are universal in Ukrainian and German, but reflect national and cultural specifics given the peculiarities of both languages and each linguoculture, as well as existing realias, norms, conventions, maxims and rules of communication.
\end{abstract}

Accepted: July 30, 2021
Анотація

Дослідження має на меті встановити особливості комунікативних девіацій як когнітивного i водночас дискурсивного феномена в українсько- і німецькомових відеоінтерв'ю 3 позиції респондентів. Процедура дослідження передбачає комплексне застосування методів і прийомів лінгвопрагматики, девіатології та комунікативної лінгвістики. Розроблено нову методологічну базу для реконструкції комунікативних девіацій із застосуванням дискурс-аналізу, а саме для реконструкції окремої події у двох дискурсивних середовищах, визначення комунікативного контексту та ситуації спілкування в інтерв'ю у зіставлюваних мовах. Результати дослідження дозволили визначити характерні ознаки комунікативних девіацій у політичних інтерв'ю на зовнішньоструктурному внутрішньоструктурному та ситуативному рівнях. Висновки дослідження свідчать про те, що типи комунікативних девіацій у політичних відеоінтерв'ю мають універсальний характер в українській i німецькій мовах, проте відображають національно-культурну специфіку з огляду на особливості обох мов та кожної

\footnotetext{
${ }^{69}$ The article has been prepared within the scope of individual scholarship of the Verkhovna Rada of Ukraine for young scientists Doctor of Sciences in 2021 (Igor Korolyov).

${ }^{70}$ Doctor of Philological Sciences, Professor Department of International Communication and Translation Ivan Franko National University of Lviv, Ukraine.

${ }^{71}$ Doctor of Philological Sciences, Professor Department of Polish Studies Taras Shevchenko National University of Kyiv, Ukraine.

72 Candidate of Philological Sciences, Associate Professor Department of German Philology Ivan Franko National University of Lviv, Ukraine.
} 
Keywords: communicative deviations, German language, political video interviews, respondent, Ukrainian language.

\section{Introduction}

At the present stage of modern communication oriented linguistics the spheres of scientific knowledge expand and the examination of fundamental and universal notions. The phenomenon of communicative deviations remains one of the most debatable (Batsevych, 2000; Deppermann \& Reinhold, 2008; Dyakiv, 2018, Dyakiv, 2019; Janicki, 2017; Kapeliushnyi, 2000; Mustajoki, 2017; Voitsekhivska, 2019). That not only bring discomfort in the relationship between speakers, but can also lead to a general misunderstanding, resulting in the interruption of the act of communication both within one and various linguocultures, which is confirmed, among other things, by the examples from world politics.

Humanities studies even witnessed the emergence of a new discipline as a separate science - deviatology, which formed two main approaches to communicative deviations: interdisciplinary and specialized. Interdisciplinary approach is reflected in philosophy, psychology, pedagogy, methodology and didactics, culturology, intercultural communication, conflictology, orthology and journalism. Specialized approach is represented by the works of linguists, who researched communicative deviations in the actual theoretical, communicative, sociolinguistic and contrastive aspects, as well as in cognitive (Dubtsova, 2014) and discoursetextual (Grice, 1975; Milchenko, 2011; Pechko, 2011), with the latter two being essential for the research.

Such systematization of scientific literature on the researched issue allowed to assume that communicative deviations as a phenomenon are characteristic of all types of speech genres, especially of interviews with various political figures (Friedrichs \& Schwinges, 2005; Haller, 2013; Häusermann \& Käppeli, 1986). Thus, we can talk about a new area of research - cognitivediscursive deviatology, in which the analysis of deviations will be based on new and still undeveloped theoretical and methodological principles (including discourse analysis), from the standpoint of which one can identify the causes of communicative deviations and classify лінгвокультури і наявних у ній реалій, норм, конвенцій, максим і правил спілкування.

Ключові слова: комунікативні девіації, німецька мова, політичне відеоінтерв'ю, респондент, українська мова

them according to various criteria, offering communicators an algorithm to avoid misunderstandings, failures, to resolve any possible conflicts or prevent any conflict situations and improve social and intercultural communication (Földes, 2007; Schulz von Thun, 2010), and that determines the relevance of the research.

The objective of the publication is the establishment of the peculiarities of communicative deviations as a cognitive and, at the same time, discursive phenomenon in Ukrainian- and German-language political video interviews from the viewpoint of the respondents, namely of such method as discourse analysis. The formulated objective provides for the solution of the following tasks: 1) to clarify the definition of the concept of "communicative deviation" as a dynamic and complex cognitivediscursive phenomenon; 2) to determine the types of reconstructed communicative deviations of the respondent at the structural level from the standpoint of pragmatics; 3) to characterize the patterns and differences of the reconstructed types of communicative deviations of the respondent in Ukrainian- and German-language political video interviews in terms of quantitative and qualitative indicators.

The article consists of a theoretical, methodological part, results, conclusions and a list of references.

\section{Theoretical Framework}

Based on the theoretical postulates, a new methodological basis is developed in the research for the reconstruction of communicative deviations using a comprehensive approach to the analysis of the object of scientific reflection and methodological principles, namely through discourse analysis - for the reconstruction of a single event in two discursive environments, defining the communicative context and communicative situations of a specific type of interview in compared languages. After all, the concept of discourse includes not only what is said and written, but also what is not desirable or not allowed to say or to write, or what is 


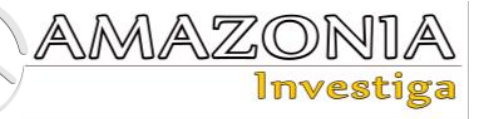

generally unthinkable or unspoken due to lack of thematization. Accordingly, the studies of oral speech do not describe styles, but specific language-speech units and structures (at the level of prosody, vocabulary, syntax and text) in connection with different functions of language (interactional, structuring conversation, semantic) (Schwitalla, 2012). Although discourse analysis is based on the methods of text linguistics and oral linguistics and is related to the analysis of conversations, its key interest lies in current social issues, human worldview and which linguistic means are employed in the process (Larcher, 2015: 11). That is why there are two approaches to the concept of discourse: the production of socially recognized knowledge and the processes of (political) interpretation and negotiation.

Given the definition of video interviews as an integrated informative variety of the interview genre, i.e. the speech genre (= communicative genre), there are genre-structural levels, at each of which, we believe, the communicative deviations occur. We will consider these levels in more detail below (Günthner, 1995: 201):

1. The external structure includes the communicative and social environment in which the communication takes place, a specific group, institution, gender, i.e. all factors related to the context that are not formed in the interaction. This can be a place or time of the meeting, as well as the clothes. At this level, we consider it appropriate to distinguish, besides the violations of the preparatory conditions of communication, the types of violated communicative acts (Batsevych, 2004: 216-220), in particular, such as the unexpected and violated expected communicative acts of the respondent.

2. The internal structure includes verbal and non-verbal intra-genre components of the communicative event. Verbal components include phonological variants, lexicosemantic phenomena, morphosyntactic elements, dialectal speech factors, stylistic and rhetorical figures, text structuring, idioms, thematic interview blocks, etc., and nonverbal - prosody, voice specificity, gestures and facial expressions (Günthner, 1995: 201).

3. The situational level of realization includes "phenomena that relate to the interactive context of dialogic exchange between communicators and the sequential nature of utterances" (Günthner, 1995: 203). It is an intersubjective and situational intermediate structure, also called a situational level of realization or a level of interaction (Günthner, 1995: 16). At this level we refer to the sequence of individual statements and the distribution of the right to speak, about changes in topics, but also about the relationship between communicators. That is, we are talking about the classic issues of discourse and conversational analysis, such as: sequence, change of speakers, paired sequences, predominant structures, the format of expression and the status of communicators and reactions of recipients. Accordingly, such structural units of the interview are represented by pairs of remarks of the interviewer and the respondent - the dialogic units that have clearly defined formal boundaries.

The communicative deviations at the situational level in the context of the interview reflect a violation of P. Grice's maxims (Grice, 1975), such as: 1) the amount (completeness) of information; 2) quality of information; 3) compliance (relevance); 4) manner of expression (manners). Such maxims are impossible to think through in advance during the interview, because they spontaneously arise at the question - answer intersection, and, therefore, belong to the situational level.

The research methodology taking into account these levels is described in the next paragraph.

\section{Methodology}

The article presents a new theoretical and methodological concept for the performance of a cognitive and discursive reconstruction of communicative deviations of the respondent in Ukrainian and German video interviews from the position of cognitive comparative linguistics and contrastive typological linguistics. A comprehensive interdisciplinary methodology of cognitive-discursive reconstruction of communicative deviations in Ukrainian and German-language political video interviews has been developed, based on methodological principles of research, approaches to analysis of communicative deviations in video interviews taking into account the sample, thematic and statistical data.

The source base of the research is comprised of video interviews in Ukrainian and German languages for the years 2000-2019 from online video hosting Youtube, containing materials from official TV and Youtube channels as well as the programs of individual Youtube users. The 
interviews that received the most views based on the use of search filters on YouTube and placed in the "Trending" section were taken into account. The criteria for selecting the interview were also determined by: the importance of the respondent's persona, the relevance of the interview topic, the atypical situation, the written comments of YouTube viewers after watching the video. The factual material of the research consists of 198 political video interviews in Ukrainian and 93 in German with communicative deviations present, separated from the overall sample of 400 video interviews in each language.

Documentation of factual material is provided by discourse and conversation analysis, which covers two main requirements for empirical work: the "naturalness" of interaction situations and the detail of the transcript for analysis (Gülich \& Mondada, 2008).

Accordingly, transcripts using research-relevant elements of a dialogic discursive practice analysis scheme (Deppermann, 2008) and considering certain FOLKER transcription rules for minimal transcription (Schmidt \& Schütte, 2010) contain the following characteristics: 1) words and spaces that denote boundaries between words; 2) hesitation signals; 3) laughter and crying; 4) signals of perception; 5) pauses; 6) non-verbal means; 7) incomprehensible fragments; 8) deleted words and sentences; 9) superimposition of the speaker's remark on the previous remark of the communication partner or simultaneous speech. Abbreviations relevant to the research are also introduced: 1) identification of the interviewer's remark: I: / I :; 2) identification of the respondent's reply: P:/R:; 3) appellative intonation: ?; 4) emotional tone:!.

Let us address the procedure of communicative deviations research. Methodological operating procedures were applied within the four main stages of the study. On the first stage, on the basis of elaboration of theoretical achievements of domestic and foreign linguists in the field of studying interviews and communicative deviations, the genre of Ukrainian- and Germanlanguage video interviews is identified and systematized, the corpus of political interviews and their role in the social context in both linguistic cultures. On the second stage of the study, the types of deviations by structural level are compared. On the third stage, the factors of communicative deviations in video interviews, which depend on the respondent at different structural levels of the genre, are reconstructed (in values and characteristics). The fourth stage compares the types of communicative deviations in video interviews in both linguistic cultures, their qualitative and quantitative description using the obtained statistical data to verify the conclusions.

Such synthesis of genre interpretation (speech = communicative) in Eastern and Western European linguistic traditions has proved promising in the study of political video interviews in unrelated languages, as shown in the results of the investigation below.

\section{Results and Discussion}

The theoretical stances are formulated based on the works on problems of pragmatics, deviatology and communicative linguistics, cognitive linguo-comparative studies, the main of which are:

1) The practical term "communicative deviations" in this research has a narrow meaning of differences, discrepancies in the expectations of the communicators, caused by the interviewer, respondent or discursive environment (in a broad sense), which is a deviation for one of the communicators or viewers; as a phenomenon that arises, acquires features and is subject to correction in video interviews within the studied linguistic cultures; and in a broader sense it is an "umbrella" term for speech, linguistic and extralinguistic deviations, a universal and at the same time ethnoculturally marked, dynamic, complex cognitive-discursive phenomenon, which is specifically generated in various formats and genres;

2) cognitive-discursive reconstruction provides a universal model of communicative deviations of the respondent in Ukrainianand German-language political video interviews at the structural level (external, internal and situational) of this speech genre.

It was recognized that communicative deviations are more common in Ukrainian- $(47.1 \%$ of the total sample) than in German-language video interviews (38.9\% of the total sample), among which political video interviews account for $49.5 \%$ in Ukrainian and $23.3 \%$ in German linguocultures. Compared to other types of interviews (for example, sports, celebrity), the subject matter of which is related in both linguocultures, communicative deviations in political interviews differ thematically, due to the specifics of political life, as well as the culture of political communication in both linguocultures. The communicative deviations of the respondent 


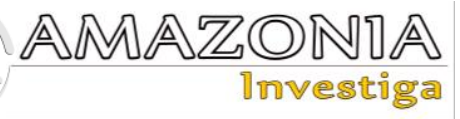

are present in political video interviews at three identified levels:

\section{External structural level:}

1) deviations in unexpected communicative acts:

a) unwillingness to start communication (Ukrainian: $62.3 \%$, German: 3.1\%), namely short answers that indicate unwillingness to listen to the interviewers and answer their questions:

I: (-) Скажіть будь ласка (-) чи бачили Ви ролик "100 днів президентства Зеленського”? (- -)

$P: \boldsymbol{H i}(-)$

I: Чому немає Вас там? (-) С всі президенти (-)але немає Вас(- -)

Р: Я до нього (-) до цьього роліка не маю ніякого відношення (- -)

I: А до Вас зверталися по коментарі? (-)

P: Мені про це невідомо! (-) (Ukrainian Pravda, 3.09.2019);

b) unpreparedness for communication (Ukrainian 56.8\%, German 14.1\%), the inability and unwillingness of the respondent to answer spontaneous unexpected critical questions of the interviewer lead to incompetent answer and avoidance:

I: Я кажу щчо Ви (- -) Чому Ви тікаєте? (- -) ((..)) I зникнете знову (-) Ви ж вдруге уникаєте запитання (- -)

Р: Я завтра буду (-) і післязавтра буду (-) (Artem, 2019);

2) deviations in the expected communicative acts with joint presuppositions:

a) a strategically planned own concept of the interview, which does not coincide with the concept of the interviewer (Ukrainian $32.2 \%$, German 28.1\%). After the PACE meeting, Olga Skabeeva, a Russian journalist of the program "60 minutes" tried to interview the members of the Ukrainian delegation, and instead of response she heard Ukrainian national anthem. The respondents refused to answer her questions and ignored the interviewer's attempts to shout over them (Radio Svoboda, 11.08.2018);

b) the substitution of the presuppositions of the interviewer or attribution of other presuppositions to the interviewer (perception of him as competent) (Ukrainian $8,1 \%$, German $14,1 \%)$ :
R: Ich finde, er hat doch ganz konstruktiv gesprochen...

I: Ich glaube, er hat nur gesagt: Na ja, dann ist es halt jetzt eben so. So kam es mir vor.

R: Dann ist es gut.

I: Das reicht Ihnen?

R: Da haben wir schon Kontroverseres (Merkel, 2020);

c) perception of non-existent implicatures of discourse (hint, irony, where there is none), inferencing of non-existent illocutionary forces (Ukrainian 12,2 \%, German 17,2 \%):

I: Я жн не про список (-) а про мажоритарну систему.

Р: А я вам (- -) пані про те щцо (- -) пробачте (- -) я зараз (- -)

I: Ви не знасте?

P: (- -) Я все знаю (- -) (Direct TV Channel LLC, 12.09.2019).

\section{Internal structural level}

The level of internal structure includes the following communicative deviations, that are more about rhetoric and style, the ability to push the person's own position and to dismiss any unpleasant question:

1) code switching - mostly from Ukrainian to Russian in a state of agitation and concern (Ukrainian 72,8 \%):

P: Ще раз Вам кажу (-) я отримаю інформацію щзо Ви той хто є на самом деле (-) офіцийно (-) $i$ тодi буду с Вамі (- -) розмовляти ((...))(Artem, 2019);

2) conversational style, not typical for political videos (Ukrainian 48,3\%, German 3,1\%):

Р: Дуже класна тепла атмосфера (-) дуже зустріч була конструктивною (- -) Я побачив перед собою дійсно лідера об'єднаної Європи (-) Мені сподобалось (- -) Га? (-) (Radio Liberty Ucrania,12.04.19),

3) Russianisms (Ukrainian 85,2 \%):

I: ((...)) Можливо зараз вже попереджають $i$ годинники не одягати? (-) Каблучки (-) діаманти (-) сережки (-) все залишити вдома? (-)

P: Ну ие навіть як в иутку виглядає (-) насправді якби серйозно (-) ия тема не обговорюється (-) (TV channel $1+1$, 16.10.2013); 
4) repetitions (Ukrainian 24,6 \%, German 15,5 $\%)$ :

I: А чим займаються Ваші підприємства? (-) $P$ : ((getting into the elevator $))$ До побачення! (-) До побачення (-) я закінчив(-) все! (- -) Пані (-) я не знаю як Вас звати (-) але Ви ведете себе абсолютно якось безглуздо (-) Абсурдні запитання! ((...)) (BIHUS info, 27.11.2016);

R: Ich frag Sie das jetzt. Vielleicht kann der zuständige Redakteur hereinkommen und erklären, was bei diesem Bericht jetzt neu war.

I: ((...)) Meine Frage ist an Sie: Können Sie weiterhin im Untersuchungsausschuss bleiben?

R: Meine Frage an Sie ist, warum der ORF einen Bericht, den er schon am 19. August 2008 1:1 gesendet hat, zwei Jahre später 1:1 wiederholt. Warum machen Sie das, Herr Leitner? (Petzner, 13.07.2012);

5) answering a question with a question (Ukrainian 21,5\%, German 18,6\%):

P ((sighs heavily)) Я запитання до Вас зроблю (-) скільки прогресивний президент Польщі Квасневський посадив у тюрми? (- -) Я Вам розкажу один секрет (-) Ви знаєте (-) щео президент не садить у торми? ((...))(Ukrainian Pravda, 13.08.2018).

R: Herr Tarek (- -) Leitner (- -) Ähm (- -) erlauben sie mir Folgendes eingangs zu sagen (-) Sie können mir jede Frage stellen (-) aber (- -) ich möchte mit einer Gegenfrage beginnen (- -) Und Sie (- -) Sie sin a seriöser Journalist vom ORF (- -) fragen (- -) Was ist an dieser Geschichte jetzt neu? Wo liegt der Newswert an diesem Bericht? (Petzner, 13.07.2012);

6) pejorative language (Ukrainian 6,8 \%):

I: Цього року Ви також побували на Свро-2016 (-) Які враження взагалі про футбол?(- -)

Р: Дуже хренові враження (- -) ((laughing)) від чемпіонату (-) Немає у людей патріотизму (-) от немає (-) Ïх би на тиждень з автоматами на передову(-) я думаю вони б тоді побігали (-) $\boldsymbol{Я}$ злий страшно і недобрий за тей футбол (- -) (Kozlovskyi, personal, 25.10.2016).
7) questions indicating surprise (Ukrainian $32.2 \%$, German $28.1 \%$ ):

I: (- -) Якще від Ігора Мірошниченка вже багато чого можна очікувати (-) то від Вас таких дій не чекали (- -)

P: ((facial expressions and intonation of surprise)) А можна запитати яких? (-) (TV channel 1 + 1, 2018);

8) irony (Ukrainian 17.1\%, German 23.4\%), sarcasm (Ukrainian 6.8\%, German 4.7\%):

I: Ви почали душити людину як мінімум (-) P: Та ви шо??? Дуже дякую шо Ви мені сказали (-) а то я цього не знав ((laughing)) ((...)) (TV channel $1+1,2018)$.

$R$ : Journalisten sind Nazi oder...

I: Ich bin kein Nazi. ((...)) Wie können Sie sagen, dass ich ein Nazi bin? Zahlen Sie erstmal Ihre Gerichtskosten? (Hofreiter, 08.09.2018).

I: Ich habe jetzt noch nichts gesagt (- -)

R: Sie haben aber gerade Luft geholt (- -) um etwas zu sagen. (Petzner, 13.07.2012).

9) syntactic incoherence of sentences (Ukrainian 58.2\%, German 26.6\%):

I: Was macht denn dann das Viagra da drin? (- -)

R: Schön-Wetter-Demokraten (- -) Und wir ziehen uns jetzt in einen Sturm und uns fehlen (-) da hat Recht im Moment, die Antworten und die Mittel und deshalb laufen die Leute (- -) wie ich finde nachvollziehbar (- -) orientierungslos durch die Gegend (- -) (Strunz, personal, communication, 13.04.2017).

Non-verbal means (Ukrainian: 73.3\%, German: $35.9 \%$ ) include a skeptical look from under the glasses, which shows falsehood and pretentiousness, an agitated and trembling voice, dissatisfied facial expression of the respondent, lack of eye contact between the respondent and the journalist and the public, for example, in the following interviews (Slidstvo, 01.12.2014, “World, 2019): 


\section{AMAZONIA \\ 1nvestiga}

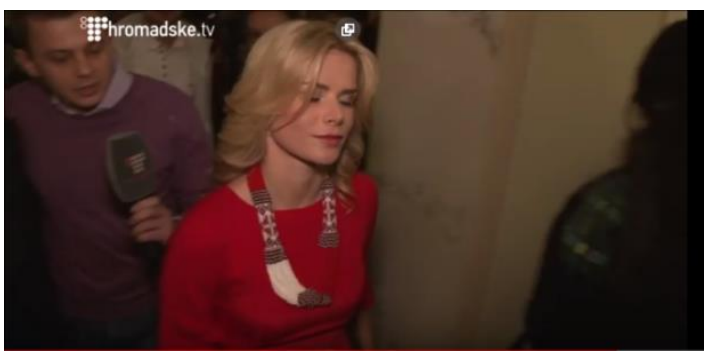

3. Situational level:

1) violation of the information quality maxim (Ukrainian 26.7\%, German 29.7\%), inappropriate or abstract answer to the question:

I: (- -) Але ие найдорожчі бренди і останні тендениії?? (- -)

Р: Справжня жінка повинна виглядати як дівчина (-) поводитися як дама (-) мислити як мужчина (-) і працювати як кінь (-) (TV channel 1 + 1, 05.11.2012);

$R$ : Noch mal (-) So undifferenziert bekommen Sie von mir dazu keine Antwort (-) (Pretzell, personal communciation, 2018).

2) violation of the completeness of information maxim (Ukrainian 26.0\%, German 23.4\%):

I: Пані Тетяна (-) добрий день (-)

Р: Можна я карточку свою заберу (- -) ((running away from the journalist))

I: A дасте нам коментар? (-)

$P$ : ((running away from the journalist $))$ Пomin da. (- -) (Slidstvo, 01.12.2014).

I: Also erstmal die Aktivität der FPÖ hat man ein wenig am Hut getrieben. (interrupting)

R: So eine Schwesterpartei...( interrupting)

I: Wir können draus lernen, weil die Sozialdemokratie in Rumänien sprechen (...) Vorschläge...( interrupting)

R: Die Kräfte mit FPÖ-Leuten (...). Oder würdest du hier mit der Schwesterschaft aufkündigen? Dann sag bitte...( interrupting)

I: Also die Verwandtschaft kann man sich nicht aussuchen.

R: Aber ihr seid verwandt.

I: Das hast du doch gesagt...( interrupting) (Ntv news, 29.05.2019);

3) violation of the relevance maxim (Ukrainian $47.9 \%$, German $37.5 \%$ ), a long tirade or monologue, which makes it impossible for the interviewer to ask the question:

P: Марічко (-) Ви знаєте (-) я поміняв би ситуащію (- -) Це не нам з ними жити (-)

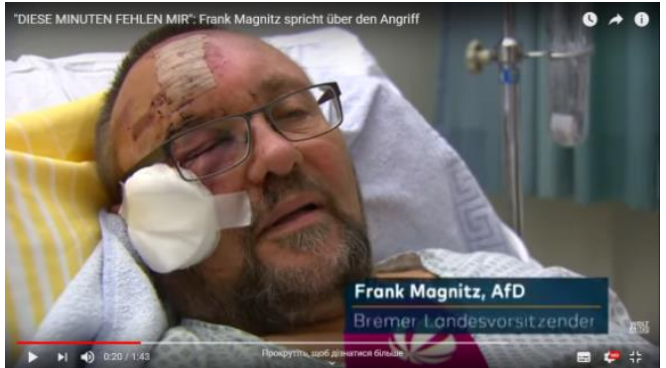

тому шо їм для життя взагалі нічо не потрібно(- -) Прийшов (-) купив семкі(-) включив “Вечірній квартал” (-) паржал (-) випив пиво (-) у ніх всьо харашо (-) а завтра буде світити сонечко (- -) А в нас шо війна в краӥні (-) та ой Господи(-) яка війна? (-) В них все прекрасно (-) Це плінтусне населення ((over 2 min long monologue)) (- -) Вони $\epsilon$ такий (-) отака глиба маргарину (-) отаке розтоплене (-) знаєте (-) така глиба (-) по якому ніж проходить за одну секунду (-)

I: [Добре]

P: [Ми дуже легко] пройдем ињю глибу (-) якшо захочемо (Drozdov, 10.02.2018).

I.: Die CDU bezieht mit ihrem Regierungsprogramm klare Positionen (- -) Wo liegen die Unterschiede zu den politischen Mitbewerbern?

R: Also (-) wir sagen (- -) Erstens (- -) wir wollen keine Schulden auf Kosten der nachfolgenden Generationen machen (- -) Zweitens (- -) wir haben Spielräume dadurch (-) dass wir sehr viel beschäftigte Erwerbstätige haben und deshalb wollen wir kleine und mittlere Einkommen entlassen (- -) ((Monolog, über 2 Minuten lang)) Keiner wird mehr belastet (- -) kleine und mittlere Einkommen werden entlastet (- -) (Merkel, 2020).

4) violation of the manner of communication and the principle of politeness maxim (Ukrainian 63.7\%, German 17.2\%):

a) the respondent interrupts the conversation and runs away from the interviewer (Ukrainian: $32.2 \%$ ):

P: Я Вам $і$ так нормально кажу (-) відстаньте від мене до здачі (-) потім nidxодьme (- -)

I: Зупиніться будь ласка (-) Ви ж пообіияли! $(-)$

P: ((running away from the journalist)) $\boldsymbol{A}$ перевищив ліміт (- -) я спізнююся ((...)) (Mamioc, 27.11.2016).

I: (gehobener Finger) Und so hält das auch? ((unverständlich)) 
R: Wenn ich noch kurz sagen darf (-) (Merkel, 2020);

b) referral to third parties (Ukrainian 26.0\%, German 23.4\%):

I: [I яка сума] (-) ну якщо не секрет?(-)Це сотні тисяч доларів? (-)

P: Це у Леся запитайте (-) (TV channel $1+1$, 16.01.2015).

c) missing or unsuccessful metacommunication, as respondents point to the distortion of facts, insults or persecution of journalists (Ukrainian 31,8 \%, German $17,2 \%)$ :

P: Знасте (-) будьте серйозніші ((nervous facial expressions and gestures)) (-)

I: Я не маніпулюю (-) я говорю факт (- -)

$P: \quad$ Ви говорите штампами які Вас принижують як журналіста (-) Ви дрібнуваті стаєте (-) дрібнуваті (- -)

I: Я Вас не образити хотів (- -)

Р: Ви вживаєте штамп слабких людей (-)

(Ukrainian Pravda, 13.08.2018).

R: Ist der Inhalt des Videos okay? (-)

I: Welches Video?(-)

R: Du kennst das Video auch nicht? (-) (Ntv news, 29.05.2019);

d) indication of facts distortion (Ukrainian 23,5 $\%$, German $8,6 \%$ ):

P: (- -) Розумісте (-) говорити про иее зараз просто нонсенс (-) Ви просто перекручуєте факти (-) фактів таких немає шо він ігнорує повістки (-) тому щзо повісток немає (- -) $\boldsymbol{B u}$ просто-напросто говорите то чого немас (-) А потім запитусте (-) чи може бути те чого немас (- -)

I: Пане Чумак (-) я факти не перекручую (-) це раз [А по-друге] (-)

P: [саме перекручуєте] ((...)) Ви розумієте () иее називається абсолютне юридичне невігластво (-) тому що Ви перекручуєте факти (-) шо там були якісь злочини яких взагалі-то не було (- -) (Espreso.TV, 06.12.2017).

e) insults or persecution of journalists, rude behavior of the respondent (Ukrainian 17,1 $\%$, German 6,2 \%). All followed by condescending and brutal answers and unprofessional behavior of politicians (condescending and brutal answers: вчіть юридичну науку, відстаньте, я не збираюся Вам нічого пояснювати (BIHUS info,, 27.11.2016). For example:
I: Sie haben jetzt mit vielen Parteimitgliedern, mit der wirklichen Basis, heute diskutiert und gesprochen und wenn man da zugehört hat, hat man gemerkt, da gibt es schon auch noch einigen Gegenwind. Also ein Selbstläufer wird das wohl nicht, diese Befragung oder?

R: Also dann müssen Sie hier eben nicht zugehört haben, wenn Sie diese Meinung haben... das hat man vielleicht in Mainz nicht hören können (ZDF, 2015).

f) interruption of the interviewer from the beginning of the conversation, refusal to answer (Ukrainian 14,2 \%, German 1,6 \%):

I: А Вас не покличуть хрестити онука Петра Порошенка (-) який з'явиться на світ буквально за кілька днів? ((...)) Ну і я думаю щьо Ви побачите хто буде хресними ((...))

Р: Я не разумію такого терміна (-) Ви будь ласка висловлюйтесь уважно $і$ коректно (-) $i$ тоді з Вами будуть спілкуватися ((...)) (TV channel $1+1$, 30.05.2014).

Overall, it should be noted that communicative deviations arise due to different intentions, purposes and strategies of communicators. Politicians are interested in self-presentation, so they mostly agree to stay only in the studio, they come to interviews on preliminary invitation with prepared questions to present themselves in a better light, if not - then failure is expected as well as complete disregard or refusal of such an interview by politicians. Fake misunderstandings (or rather a failure to understand) are also typical in order to avoid critical and uncomfortable questions from journalists. Among frequent causes for misunderstandings in Ukrainian linguoculture are the Ukrainian conflict with Russia, the question of corruption, wealth, politicians' own position on a topical issue in society, and in German linguoculture - the election programs and refugee issues.

Despite the proposed analysis of communicative deviations, the following questions remain open in the research: how to distinguish between intentional and unintentional communication disorders, how the communication strategies of both communicators interact during communicative deviations, whether it is more important to adapt the interview for the viewer or the addressee; do other types of communicative deviations arise in intercultural communication? We will proceed to the conclusions of the research further on.

\section{Conclusions}




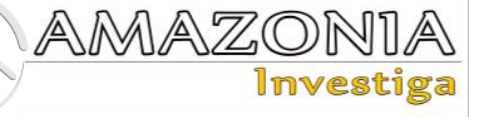

To summarize, it should be noted that the results of the research confirmed the hypothesis that the types of communicative deviations in political video interviews are universal in Ukrainian and German, but reflect national and cultural specifics given the peculiarities of both languages and each linguoculture as well as existing realias, norms, conventions, maxims and rules of communication. In general, what is common to communicative deviations in political video interviews is that in both linguocultures they are caused to a greater extent by the respondent rather than by other factors, and the causes of deviations depend on the structural levels of the genre. Verbal and nonverbal means causing communicative deviations vary because of the structural differences of both languages. Evidently, Ukrainian interviews have a significantly higher number of communicative deviations at different levels, especially in the actual linguistic level.

Thus, political interviews (Ukrainian $73.7 \%$, German $68.8 \%$ ) can be characterized by the following features of communicative deviations: 1) at the external structural level: different expectations, substitution of presuppositions of the interviewer, inferencing of non-existent illocutionary forces (for both), unwillingness to start communication, unpreparedness for it (Ukr.); 2) at the internal structural level: vocalized pauses, rhetorical questions indicating surprise, irony, sarcasm (for both), code switching, colloquial language, Russianisms, repetitions, counter-question in response, pejorative language, syntactic incoherence of sentences, nonverbal means expressing dissatisfaction (Ukr.); 3) at the situational level: violation of completeness / quality of information maxims, referral to third parties, no answer to the question (for both), violation of relevance maxims, manners of communication and politeness, interruption, lack of metacommunication (Ukr.), poor metacommunication (Ger.).

Prospects for future research include the reconstruction of communicative deviations in other genres and discourses and in different languages, as well as experimental research (survey, analysis of commentaries) of deviations perception by participants and viewers of interviews and other media genres.

\section{Bibliographic references}

Artem, A. (2019) People's Deputy Oleh Nedava is running away from Stop Corruption journalists [Video]. Youtube, https://www.youtube.com/watch?v=GVSNodaF FFg\&t=13s. (Last accessed: 15.08.2019)

Batsevych, F. (2000). Basics of communicative nine-colony. Lviv: I. Franka [in Ukrainian].

Batsevych, F. (2004). Fundamentals of communicative linnvistics. Kyiv: Academy [in Ukrainian].

BIHUS info (27.11.2016) Mathios runs away after hearing about 34 million dividends. [Video]. Youtube,

https://www.youtube.com/watch?v=WBLzCSR V-Sg\&t=9s (Last accessed: 03.01.2019).

Deppermann, A. (2008). Analyze conversations. 4. Ed. Wiesbaden: VS Verlag.

Deppermann, A., \& Reinhold, S. (2008). Understanding displays: On the phenomenology of understanding in interaction. German language, 36(3). 220-245.

Direct TV Channel LLC (12.09.2019). "I do not know. I don't understand ": the deputies could not explain how they got to the parliament [Video]. https://prm.ua/ya-ne-znayu-ya-ne-rozumiyudeputati-ne-zmogli-poyasniti-yak-potrapili-doparlamentu/ (Last accessed: 15.08.2020).

Drozdov (10.02.2018). Ostap Drozdov on the "plinth population" [Video]. Youtube, https://www.youtube.com/watch?v=f-

M65fmcPtI (Last accessed: 03.01.2019).

Dubtsova, O. V. (2014). The linguocognitive nature of communicative failures (based on American film discourse). (thesis, dis. ... Cand. filol). Kharkiv National University, Kharkiv. [in Ukrainian]. http://foreignlanguages.karazin.ua/resources/20baf11ecaba57 2a62ed6756c2ea09b8.pdf

Dyakiv, Kh. (2018). The political television interview and communication failures for journalists. Journal of German Language and Literature - Studies on the German language and literature, 1 (39), 95-107.

Dyakiv, Kh. (2019). Please write here the next text instead of the marked green text: Poor recipient design in Ukrainian and German political YouTube interviews. Inadequate addressees in Ukrainian and German political Youtube-Interviews.

Germanoslavica, 30(2), 17-40.

Espreso.TV (06.12.2017). About politics | About the fight against corruption [Video]. Youtube, https://www.youtube.com/watch?v=78XSK4zu WBU (Last accessed: 03.01.2019).

Földes, Cs. (2007). Intercultural communication: positions on research questions, methods and perspectives. Vienna: Vert present. [u.a.].

Friedrichs, J., \& Schwinges, U. (2005). The journalistic interview. Wiesbaden: VS Verlag. 
Grice, H. P. (1975). Logic and Conversation. Syntax and Semantics. New York: Academic Press. Bd. 3: Speech acts. 41-58.

Gülich, E., \& Mondada L. (2008). Conversation analysis. An introduction using the example of French. Tubingen: Niemeyer, Bd. 52: Romance workbooks.

Günthner, S. (1995). Genera in Social Practice. The analysis of communicative genres as text types of oral communication. German language. 25/1. 193-218.

Haller, M. (2013). The interview. 5 Ed. Constancy. Munich: UVK Publishing company. Häusermann, J., \& Käppeli, H. (1986). Rhetoric for radio and television: rules and examples for media-friendly writing, speaking, informing, commenting, interviewing, moderating. 1. Sauerland: Ed. Aarau.

Hofreiter, A. (08.09.2018). Meets Michael Stürzenberger in Munich [Video]. Youtube, https://www.youtube.com/watch?v=Q41Dc-

Uscbs (Last accessed: 20.02.2020).

Janicki, K. (2017). What is conflict? What is aggression? Are these challenging questions? Journal of Language Aggression and Conflict. 5 (1). 156-166. https://doi.org/10.1075/jlac.5.1

Kapeliushnyi, A. (2000). Deviatology of mass media. Lviv: PAIS [in Ukrainian].

Larcher, B. S. (2015). Linguistic Discourse Analysis. Tubingen: Fool. https://doi.org/10.1515/zrs-2016-0024

Merkels, A. (2020). Interview with Anne Will on the 4th candidate for Chancellor. ARD Mediathek.

URL: https://www.tagesschau.de/multimedia/video/vi deo-122489.html (Last accessed: 19.01.2020).

Milchenko, O. S. (2011). Semantic deviations in normative legal texts. (Unpublishedcandidate's dissertation). Taras Shevchenko National University of Kyiv, Kyiv. [in Ukrainian].

Mustajoki, A. (2017). Why is miscommunication more common in everyday life than in linguafranca conversation. Intercultural Pragmatics. Amsterdam: John Benjamins Publishing Company. 55-74. https://doi.org/10.1075/pbns.274.04mus

Ntv news (29.05.2019) Somuncu grills AfD man Brandner [Video]. Youtube, https://www.youtube.com/watch?v=NbX-

mobmI8w (Last accessed: 15.08.2018).

Pechko, N. M. (2011). Linguocognitive and discourse aspects of misunderstanding as a type of interpretation (based on English dialogic speech). (dis. ... cand. filol. Ciencias). Ivan Franko National University of Lviv [in Ukrainian].

Petzner, S. (13.07.2012). Stefan Petzner does the Stronach in the ZiB 2 interview [Video]. Youtube,
https://www.youtube.com/watch?v=lub9Sqboex s (Last accessed: 15.08.2018).

Radio Liberty Ucrania (12.04.2019). Zelensky told about the meeting with Macron [Video]. Youtube,

https://www.youtube.com/watch?v=0cYEd-

Zvp9c (Last accessed: 03.01.2020).

Radio Svoboda (11.08.2018). Anthem of Ukraine on Russian television. [Video]. Youtube,

https://www.youtube.com/watch?v=FbZZ-

AkfwJ8\&vl=uk (Last accessed: 03.01.2019).

Ukrainian Pravda (13.08.2018). "I did not bring Yanukovych to power"-Viktor Yushchenko [Video]. Youtube,

https://www.youtube.com/watch?v=lQH-

1d7Ss8E\&ab_channel=\%D0\%A3\%D0\%BA\%D

$1 \% 80 \% \mathrm{D} 0 \% \mathrm{~B} 0 \% \mathrm{D} 1 \% 97 \% \mathrm{D} 0 \% \mathrm{BD} \% \mathrm{D} 1 \% 81 \%$

D1\%8C\%D0\%BA\%D0\%B0\%D0\%BF\%D1\%8

0\%D0\%B0\% D0\%B2\%D0\%B4\%D0\%B0 (Last accessed: 13.08.2018).

Schmidt, T., \& Schütte, W. (2010). FOLKER: An Annotation Tool for Efficient Transcription of Natural, Multi-party Interaction. Proceedings of LREC. Retrieved from: https://idspub.bszbw.de/frontdoor/deliver/index/docId/223 2/file/Schmidt_ Schuette_FOLKER_ 2010_ Paper.pdf

Schulz von Thun, F. (2010). Talking to Each Other 1: Disorders and Clarifications: General Psychology of Communication. Leipzig: Rowohlt.

Schwitalla, J. (2012). Spoken German: an introduction. Berlin: Schmidt.

Slidstvo (01.12.2014). People's Deputy Tetyana Donets runs away from journalist $\|$ Slidstva.Info exclusive. [Video]. Youtube, https://www.youtube.com/watch?v=Gin43HHQ omQ (Last accessed: 03.01.2019).

TV channel $1+1$ (05.11.2012). Herman and the woman-horse. [Video]. Youtube, https://www.youtube.com/watch?v=GsPfg5qjN w8 (Last accessed: 03.01.2019).

TV channel $1+1$ (16.01.2015). Arseniy Yatsenyuk's skills in the Ukrainian cinema? [Video]. Youtube, https://www.youtube.com/watch?v=xZfu8bPw Gc4 (Last accessed: 03.01.2019).

TV channel $1+1$ (16.10.2013). Tetyana Donetsk doesn't want to be on the fence of the Verkhovna Rada. [Video]. Youtube, https://www.youtube.com/watch?v=OHt6WobMq0\&t=1s (Last accessed: 03.01.2019). TV channel $1+1$ (2018). How Bohdan Beniuk ran away from questions about the beating of Panteleimonov [Video]. Youtube, https://www.youtube.com/watch?v=17kWlsnrjD 8 (Last accessed: 04.03.2018). 


\section{AMAZONDA \\ 1กvestiga}

TV channel $1+1$ (30.05.2014). Oksana Bilozir: "Poroshenko is my godfather in politics" [Video]. Youtube, https://www.youtube.com/watch?v=rfQvHlGZ whY (Last accessed: 03.01.2019).

Ukrainian Pravda (3.09.2019). Why there is no Poroshenko in Boklan's interview "100 days of Zelensky's presidency" [Video]. Youtube, https://www.youtube.com/watch?v=fMUep9lw4 H8 (Last accessed: 03.01.2020).

Voitsekhivska, N. (2019). Conflict discourse in Ukrainian fiction: structural, semantic, communicative and linguocognitive aspects. (Doctor's thesis). National Academy of Sciences of Ukraine, Kyiv [in Ukrainian].

World (08-01-2019) "I MISS THESE MINUTES": Frank Magnitz talks about the attack. [Video]. YouTube, URL: https://www.youtube.com/watch?v=R1_jeObN VbQ (Last accessed: 03.01.2020).

ZDF (13.10.2015) Scandal on ZDF: Sigmar Gabriel argues with the presenter. Access: https://www.youtube.com/watch?v=0dLrZQoJO $\mathrm{wA} \& \mathrm{t}=10 \mathrm{~s}$. (Last accessed: 12.08.2018). 